\title{
Gautier de Coinci, Cinq miracles de Notre-Dame
}

\section{G. Matteo Roccati}

\section{(2) OpenEdition}

\section{Journals}

\section{Édition électronique}

URL : http://journals.openedition.org/studifrancesi/6198

DOI : 10.4000/studifrancesi.6198

ISSN : 2427-5856

\section{Éditeur}

Rosenberg \& Sellier

\section{Édition imprimée}

Date de publication : 1 novembre 2010

Pagination : 529

ISSN : 0039-2944

\section{Référence électronique}

G. Matteo Roccati, «Gautier de Coinci, Cinq miracles de Notre-Dame», Studi Francesi [En ligne], 162 (LIV | III) | 2010, mis en ligne le 30 novembre 2015, consulté le 10 janvier 2021. URL : http://

journals.openedition.org/studifrancesi/6198; DOI : https://doi.org/10.4000/studifrancesi.6198

\section{Ce document a été généré automatiquement le 10 janvier 2021.}

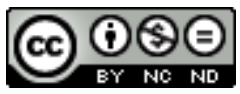

Studi Francesi è distribuita con Licenza Creative Commons Attribuzione - Non commerciale - Non opere derivate 4.0 Internazionale. 


\title{
Gautier de Coinci, Cinq miracles de Notre-Dame
}

\author{
G. Matteo Roccati
}

\section{RÉFÉRENCE}

GAUTIER DE COINCI, Cinq miracles de Notre-Dame, traduction, introduction et notes par JeanLouis Gabriel Benoit, Paris, Honoré Champion Editeur, 2007 («Traductions des classiques du Moyen Âge», 78), pp. 232.

1 Après un rappel de la vie de Gautier de Coinci, l'introduction (pp. 11-60) présente son œuvre, en particulier les caractères et les buts des Miracles de Nostre Dame, "œuvre singulière qui se confronte sans cesse à la littérature, tout en tenant à s'en démarquer» (p. 15). Sont abordés les enjeux didactiques, les contenus catéchétiques, la dimension satirique et littéraire du texte où la narration peut être très personnelle. Suit la traduction des cinq miracles (D'un clerc, De l'ymage Nostre Dame de Sardanei, Un moigne de Chartrose, Comment Nostre Dame desfendi la cité de Constantinoble, De saint Basile; traduction en prose établie sur l'éd. Koenig, T.L.F., 1966-1970). Chaque miracle est précédé d'une introduction qui en présente le contenu, les sources et l'intérêt.

2 La bibliographie des ouvrages consacrés à Gautier de Coinci (pp. 213-220) et l'index des noms propres terminent le volume. 